\title{
Remembering G. Tucker Childs (1948-2021)
}

Documentary linguist and former editor of Studies in African Linguistics, Tucker Childs, passed away on January $26^{\text {th }}$ in Portland, Oregon. We remember him as a friend, colleague, and mentor, and as a scholar who made immense contributions to the study of the Atlantic and Mel languages of West Africa, and to the field of African linguistics more broadly.

The impact of Tucker's scholarship can be felt in his fine descriptive work on the endangered Mel languages of Sierra Leone, where he first served as a Peace Corps Volunteer, and Guinea, namely Kisi, Krim and Mani. His 1995 grammar of Kisi and his 2013 grammar of Mani stand as major contributions to the documentation and analysis of Mel languages. Tucker's approach to language documentation was a passionate and holistic one, and he immersed himself in the life of the communities whose languages he studied, going to great lengths to make their languages count, long before the field of linguistics acknowledged the importance of undertaking work of this kind.

Tucker's scholarship also made an extraordinary impact in the field of ideophone studies. His groundbreaking $\mathrm{PhD}$ dissertation on Kisi in 1988 was chock-full of these sparkling words evocative of sensory imagery that continued to capture his attention throughout his career, and he went on to study them in several languages of West and Southern Africa. One of his last academic publications was a chapter in the 2019 proceedings of an international workshop on ideophones in which he, characteristically, combined acute observations from the field with perceptive questions for future research.

His broad range of interests in the field of African linguistics inspired him to write a much needed textbook, An introduction to African languages (2003), that is widely used in African linguistics courses in the United States and Europe. Always mindful of the interests of the communities where he worked, he dedicated the volume to "the victims of civil wars and other strife in Africa and to all of the bereaved family members left behind."

Tucker served as editor of Studies in African Linguistics from 2009 to 2018. Retaining a commitment to a printed version of SAL, he also moved the journal to a searchable electronic format, bringing greater visibility to more than forty years of scholarship on African languages.

Always the mentor, he was committed to finding ways to encourage young African scholars to submit to the journal, an issue he engaged with throughout his tenure as editor.

Tucker published three articles in the journal before he became editor. The first is entitled "Language typology and reconstruction: The prenasalized stops of Kisi," published in 1992 https://journals.flvc.org/sal/article/view/107417/102737, followed by a 2005 article, "The SAUX-O-V-other syntagm in Atlantic" https://journals.flvc.org/sal/article/view/107331/102652 . His last article for the journal was submitted shortly before he became editor and appeared in 2009, "What happens to class when a language dies? Language change vs. language death." https://journals.flvc.org/sal/article/view/107289/102610

Tucker will be remembered for his collegiality and generosity, for his scholarship and mentoring of younger scholars, and for his dedication to African languages and their speakers. We will miss his dynamic presence at the many conferences and workshops to come.

Fiona Mc Laughlin (Gainesville)

Mark Dingemanse (Nijmegen)

Jeff Good (Buffalo)

Friederike Lüpke (Helsinki) 